\title{
O Instituto dos Advogados Brasileiros confere a medalha "Teixeira de Freitas" ao Professor Miguel Reale, em 1968.
}

Em sessão solene do Instituto dos Advogados Brasileiros, da Guanabara, sob a presidência do Dr. Thomas Leonardos, foi entregue, no dia 18 de Dezembro de 1968, ao Professor Miguel Reale a "Medalha Teixeira de Freitas", galardão máximo conferido por aquêle cenáculo ao advogado ou estudioso do Direito considerado "o jurisconsulto do ano"

Compareceram à cerimônia, entre outros, os Ministro Luiz Gallotti $\in$ Themistocles Brandão Cavalcanti, do Supremo Tribunal Federal, o senhor Embaixador da Argentina, Prof. Mario Amadeo, os Desembargadores Alceu Cordeiro Fernandes e Otto de Souza Lima, representando o Tribunal de Justiça do Estado de São Paulo, o. Prof. Alfredo Büzaid, à testa de uma delegação de professôres da Faculdade de Direito de São Paulo; o Prof. Rui de Azevedo Sodré e outros representantes do Instituto dos Advogädos de São Paulo; o prof. Silvio Meira, na qualidade de Presidente do Instituto dos Advogados do Pará, bem como membros de outras entidades culturais e universitárias.

$\mathrm{Na}$ ocasião o Prof. Miguel Reale foi saudado, em nome do Instituto dos Aávogados Brasileiros, pelo eminente Prof. Celestino Sá Freire Bazilio, da Pontificia Universidade Católica da Guanabara. Agradecendo a 
honraria o Prof. Miguel Reale proferiu um discurso salientando o papel do advogado no mundo contemporâneo.

Eis, na íntegra, o trabalho do ilustre mestre paulista:

"Acompanhando, como acompanho, há tantos anos, as atividades do Instituto dos Advogados Brasileiros, cuja história se confunde com a consciência jurídica nacional, tenho a impressão de que o amor com que, ano após ano, conferis a medalha "Teixeira de Freitas", se reveste de profundo sentido de religiosidade.

Amor e religião seguem, aliás, de mãos dadas, pois ambos são formas de dedicação e de entrega, modos pelos quais o homem se esquece de si para se pôr face a face perante a pessoa do outro, quer procurando se relacionar com os outros homens, com o próximo, quer se atormentando na busca do obscuro "Outro", de que nos fala KIERKEGAARD, oculto pelos véus de transcendência.

Que época seria mais propícia, do que a nossa, para a religiosidade do Direito? Nós, que vivemos cotidianamente empolgados pelas medidas plásticas e flexíveis das coisas humanas, sentimos crescer, dia a dia, o nosso cuidado e a nossa angústia, tão incerto e inseguro se põe o destino do homem, cujas conquistas e realizações surpreendentes são acompanhadas de uma sombra de crescente inquietação. É que, no plano das instrumentalidades, desde o primitivo machado de silex até à mais atual estrutura de pilha atômica, bifurcam-se sempre as possibilidades de seu emprêgo, que tanto pode se iluminar no sentido da realização da felicidade e da paz como se obscurecer nas sendas da violência e da guerra.

Não há hoje no mundo nação, classe, grupo ou pessoa que se sinta tranqüilo, capaz de dispor de um quadro de valores que lhe aponte, com segurança, as suas razões de viver è de morrer. É num mundo assim estruturado que se situa o jurista, debruçado sôbre os problemas alheios, com a preocupação dominante, diria mesmo obsessiva, de assegurar a cada homem a liberdade 
de ser o que é assim como a fruição daquilo que pode fazer, numa sociedade plural, aberta à compreensão e ao auxílio mútuo.

Escrevi alhures que o que distingue o Direito, no mundo histórico da cultura, é essa sua existência perenemente voltada para os valores da alteridade. Cada homem nasce, por assim dizer, sob o sígno de um valor que marca a sua vocação. Uns se dedicam às coisas da arte, atraídos pelas imagens inspiradoras da Beleza; outros se empenham na pesquisa diuturna da Verdade, tanto mais esplendente quanto mais objetiva e transpessoal; outros ainda se exaltam seduzidos pelas glórias do Poder, sob tôdas as suas formas, desde o poder político ostensivo até às expressões do mando subreptício, oculto nas dobras da simulação e do engano; e há os servos da Felicidade alheia, nos afazeres amorosos do lar, à cabeceira de um doente, ou recebendo a prece de um moribundo. Impossivel tentar resumir as vias do destino humano, pois elas se multiplicam e se desdobram à luz das incontáveis constelaçoes axiológicas que iluminam o céu de nossa existência. condicionando também os seus eclípses, quando os valores negativos interferem e dominam o cenário com a sua negra opacidade.

Já perguntastes, eminentes colegas, que tão generosamente me fostes buscar para êste carinhoso convívio, já indagastes da natureza do valor que nos guia, a nós bacharéis em direito. atuantes no fôro ou nas hierarquias burocráticas?' Eis por certo uma pergunta ociosa e até mesmo impertinente, pois não há jurista de prol que não se tenha proposto êsse quesito ético fundamental, do qual depende a nossa significação comum nos quadrantes da vida social. Mas é exatamente por tratar-se de uma questão básica que ela se mostra inesgotável, propiciando perspectivas diversas no decorrer dos ciclos históricos, enucleando embora algo de imutável e de resistente aos desgastes do tempo. O que há de permanente no Direito. 
meus nobres colegas, é o seu heróico modo de existir em função de um valor, cuja finalidade suprema consiste em permitir que todos os valores valham, de modo que todos os fins humanos possam coexistir e harmoniosamente se desenvolver. Que é, na realidade, a Justiça senão uma exigência de ordem feita de liberdade, uma ordem que nasça da composição igual de pendores e vocações diferentes e até mesmo conflitantes, ficando assegurada a cada homem a autonomia de seu ser pessoal? Dai ter posto. como fêcho de minha Filosofia do Direito, a afirmação que a dignidade da Ciência do Direito repousa no valor da Justiça, entendida como valor franciscano, sempre a serviço dos demais valores sociais.

Mas, se todos comungamos nêsse entendimento, mister é tirar dêle as suas necessárias consequêencias. As verdades éticas fundamentais não se destinam a brilhar como estrelas distantes, para gáudio estético de alguns, ou para a aquietação da "consciência infeliz", a que se refer" Hegel. As verdades morais devem antes banhar o mundo do direito, como a luz do sol que nos aquece e ilumina. e nos condiciona e integra no processo vital, tornando-nos partícipes da insondável unidade do cosmos.

Isto quer dizer, por outras palavras, que, se o nosso destino é bem servir à coletividade, devemos nos manter vigilantes às mutações que se operam no mundo, a fim de não nos escaparem os fatos antecipadores da ordem social, que sentimos estar sendo dolorosamente gerada nos conflitos da sociedade contemporânea.

Fis ai a nossa primeira e intransferível responsabjlidade: a de ter olhos capazes de penetrar no futuro, sem nos deixarmos enganar pelo aparente e pelo transitório, por soluçōes reclamadas a altos brados, por inovadores que procuram disfarçar, com ameaças e gestos de desespêro, a inópia das idéias. a carência de diretrizes firmadas no solo firme da experiência jurídica. 
Mais do que nunca o Direito deve ser visto em sua concreta historicidade, sem se imobilizar no passado. prêso ao culto de categorias e esquemas que já não encontram correspondência nas estruturas tecnológicas e científicas de nosso tempo, mas também sem a precipitacão da mudança, como se o futuro devesse ser sorvido em haustos sôfregos de asfixiado. Na realidade, só conquista o futuro quem ama humildemente e respeita as horas presentes, sabendo infundir-lhes o conteúdo de um pensamento e o sentido ordenador da vontade.

Se, consoante antiga e sempre oportuna lição, devemos velar por uma ordem juridica que seja estável, sem ser estática, e que seja dinâmica, sem ser frenética, o que se nos impõe é a prudência de um equilíbrio em movimento, combinando o amor dos bens já adquiridos com o amor dos bens que a perfectibilidade do homem reclama.

Como tenho preferido dizer ùltimamente, e é o tema central de meu livro $O$ Direito como Experiência, o jurista é um inspirador e aplicador de modelos. Sempre o foi, aliás, embora semn plena consciência teorética, desde os primórdios da jurisprudência romana. quando os mestres do Lácio se aperceberam da possibilidade lógica e da necessidade ética de conceber a conduta humana em têrmos de categorias, espécies, gêneros, classes e sistemas, isto é, segundo "modelos ideais de ação", reconhecidos e queridos como essenciais ao bem estar da coletividade. Ora, os modelos jurídicos, consubstanciados antes em fórmulas toscas e, depois, em institutos lapidares, não os plasmaram os jurisconsultos romanos de improviso. nem tão pouco recorrendo a artifícios cerebrinos: fundiram-nos, antes, ao calor da experiência, "factibus dictaritibus ac necessitate exigente".

Não se cuide, todavia, que o Direito Romano tenha sido fruto de trabalho empirico, entregue aos azares das circunstâncias, ou mero reflexo do querer dos pretores. Como tem sido perfilado pela moderna romanística, foi 
antes filho de uma das mais nobres núpcias culturais da história, as da Filosofia grega, sobretudo aristotélica e estóica, com a experiência diuturna e prudente dos jurisconsultos romanos, cujo título era honraria suprema tanto na República quanto no Império.

Mais tarde, quando começou o degêlo da barbárie no continente europeu, foram ainda os glozadores medievais que ajudaram a modelar o "homo novus", prestes a arremeter-se em surpreendentes aventuras, nos domínios da terra e do espírito. Hoje ainda admiramos, nas ruas de Bolonha, as estátuas com as quais o povo agradecido reverenciava àqueles magnânimos, que souberam se inspirar nas matrizes romanas para oferecer os modelos de acão reclamados pelas exigências de sua época.

Se volvermos os olhos para a história moderna e contemporânea, encontraremos sempre, onde quer que ela atinja momentos culminantes, os juristas no papel que lhes é próprio, de artistas das formas ideais dos comportamentos válidos, das categorias do lícito e do ilícito, dos esquemas práticos reclamados pela problemática binada da tradicão e do progresso, da preservação e do desenvolvimento.

No Brasil, eminentes amigos, ninguém melhor do que TeIXfira DE Frertas soube encarnar a figura do verdadeiro jurisconsulto, pés imersos no humus da "lex lata" para a intuição genial das soluçõè "de lege ferenda". À sua obra deu o título modesto de Esbốço, mas esta designação, na sua singeleza, traduz a consciência de um trabalhador de modelos, de um delineador do futuro.

Já é tempo de nos capacitarmos, novamente, de que nos cabe a tarefa fascinante e temerosa da modelagem do social, para que não legislem os afoitos e os despreparados, afundando as suas mãos inexperientes no pobre barro de que é feita a criatura humana. Não, nấo nos iludamos, nós os juristas, pensando poder transferir aos legisladores, muitas vêzes jejunos de Direito, a responsabilidade das 
leis más, feitas de afogadilho, destituídas de lucidês lógica e de claridade ética. No fundo, seremos sempre nós os responsáveis, pois nossa será sempre a palavra final, como intérpretes e aplicadores da lei. Melhor é então conservar-mo-nos alerta desde o decisivo momento nomogenético, sugerindo e criticando os legisladores com serena veemência, à vista dos projetos de lei em elaboração. Imprescindível é sobretudo que projetemos no palco da opinião pública esboços e modelos normativos elaborados após aturada e amadurecida pesquisa.

Não penseis que me iludo reivindicando o primado do Direito num mundo que só parece ter olhos e ouvidos para os técnicos da automação e da cibernética, dos computadores eletrônicos e das naves interplanetárias. O que vos digo é algo bem mais simples e achegado às contingências humanas: nenhuma conquista no plano das máquinas e das ferramentas, por mais subtil e revolucionária que seja, adquire significação real para o homem até e enquanto não se ordena na medida do humano, numa rede de relações intersubjetivas, tecida por muitos fios, entre os quais um fio humilde, sem beleza aparente, não raro tosco e duro, como é próprio de sua função, que é a de urdir e suster a trama, para permitir que esplendam o desenho da composição e as cồres do bordado. Ésse fio humilde, que se afunda no solo da vida, para que esta melhor floresça, é o Direito; e nós somos os seus humildes tecelões. A matéria prima? As esperanças e os anseios, as angústias e os interêsses, os impulsos e os ideais do homem, de todos os homens de todos os quadrantes da terra.

Direis que idealizo, que, em revide a tantas objugatôrias lançadas à face dos bacharéis, a começar por algumas oriundas de bacharéis frustrados tento criar em vão um personagem fantástico, o do homem da lei capaz de exercer alguma influência no seio de seu povo. Não há, porém, sequer necessidade de retrucar a ataques movidos aos bacharéis, pois, de uns tempos para cá, até que 
temos sido poupados, não por nos reconhecerem méritos, mas antes por já nos considerarem pessoas superadas e inofensivas. As leis não nos cabem mais como tarefa fundamental, mas aos técnicos e aos economistas, vedetas da política do desenvolvimento. Quando muito nos ouvem para uma revisão formal, como a uma espécie de gramáticos especializados em linguagem jurídica, processando-se tudo de acôrdo, aliás, com o insignificante papel que os conformados neo-positivistas reservam, hoje em dia, aos estudiosos do Direito. .

Mas quem não percebe que muitos dos erros que andam por aí atormentando a Nação resultam do afastamento do jurista, trocado pelo militar ou pelo economista, pelo físico ou pelo antropólogo, sempre com o sacrifício do "sentido de conjunto", da compreensão unitária e orgânica dos problemas sociais, que o bacharel cultiva por natural vocação, e que é a condição sem a qual não se organizam as sociedades, nem se preservam as fontes do progresso?

O que reivindico é, pois, apenas e tão sòmente aquilo que por direito nos cabe, e é essencial à autenticidade da vida democrática: o direito e o dever de colaborar positivamente na estruturação da ordem jurídica. sem ficarmos adstritos ao papel subordinado de assessores, mas sim com a responsabilidade conatural a quem montou a sua norada no âmago da experiência social.

Para tão altas responsabilidades, todavia, - reconhecâmo-lo em corajosa autocrítica, - torna-se urgente a revisão de nossas categorias e processos de trabalho. Ainda não nos demos conta de que continuamos caudatários da Dogmática Jurídica do Século XIX, tôda elà fundada na teoria retrospectiva das "fontes do direito". tôda ela alicerçada sôbre uma concepção do "Estado do Direito" puramente formal. na qual a técnica jurídica se reduz a um engenhoso mas precário sistema de pesos e contrapesos. 
O Estado do Direito e da Justica Social, que se esculpe na consciência atuante de nosso tempo, deve estadear-se em novas e corajosas estruturas jurídicas, superando-se de vez uma situação paradoxal, na qual os organismos forenses, menos por defeito dos homens do que por deficiência de estrutura, parecem existir mais para resolver problemas da máquina judiciária, ou para apreciar simples questões de forma, do que para dar resposta adequada e pronta aos conflitos de interêsses.

$O$ mundo transformou-se e se transforma a olhos vistos; os processos de comunicação e informação alteraram e continuam transmudando a face do planeta; o Estado, ôntem absanteista e apático, hoje se agiganta, como o "monstro frio" anunciado por Nietzsche, a tudo e a todos querendo substituir; o jôgo das aventuras individualistas e das intuições criadoras de empresários geniais, é substituído pela programação objetiva e impessoal dos cálculos eletrônicos: o futuro a todo instante se põe como componente primordial das soluções normativas, ao serem traçados planos de desenvolvimento tecnológico e econômico, graças aos quais se pretende subordinar os eventos de amanhã às providências cautelares de hoje; tudo, em suma. se ordena numa visão prospectiva e concreta da existência, e nós juristas continuamos, imperturbáveis, a manejar nossos antigos instrumentos de análise, os mesmos que serviam aos juristas da Escola da Exegese nos dias aparentemente tranqüilos da "belle époque" .

Quem ousaria contestar que o Direito de hoje ainda se conserva um Direito cartulário, servo de antigas fórmulas e rotinas, que são entraves à obtenção da justiça concreta?

Como é triste, por exemplo, a um advogado falar perante um juiz prisioneiro do sistema vigente. que o mantém álgido e distante, encerrado no casulo de um diálogo desigual ou impossivel. Como é decepcionante e 
desanimador ouvir, às vêzes, o desenrolar de um juízo fundado em falsas e inexoráveis premissas, e nada se poder aduzir, nada se poder objetar, a bem da verdade e da justiça que ambos, o advogado e o juiz, temos em vista atingir!

Não é menos triste o desenlace melancólico de demandas, comprometidas pela inexperiência ou pela temeridade de um profissional, sem que ao juiz seja dado interferir, em virtude do apequenamento que tem prevalecido na compreensão das atribuições reais do magistrado, sobretudo no instante crítico do despacho saneador?

Dir-se-á que sempre assim foi e que sempre assim será, tais são as deficiências e misérias humanas. Quando, porém, o que devia ser exceção ganha terreno de normalidade, mister é que se revejam as estruturas do Direito, a começar pelas do ensino universitário; imprescindível é que se renove o arcabouço lógico da Ciência Jurídica, e se cuide, com não menor afinco, da reforma das atitudes, graças a uma compreensão mais viva do papel que advogados e juízes, delegados e promotores exercemos no seio da comunidade. Tudo está a reclamar, em suma, a revisão do Direito, em sua estrutura e em sèu espírito, a começar pela formação de profissionais que efetivamente correspondam às conjunturas da "nova sociedade industrial", onde a advogacia contenciosa vai cedendo ámplo espaço à advocacia preventiva e suasória; onde as especializações vão deixando de se realizar em termos de disciplinas jurídicas, para se dar em função de setores econômico-sociais; onde a tarefa do advogado talvez venha a ser menos a de interpretar códigos e arestos de jurisprudência do que a de conceber e aplicar complexos modelos negociais. e não menos complexas estruturas normativas exigidas pela praxis administrativa do Estado de cultura e do bem estar social.

Advogado e professor, seduzido pelos valores da Política e da Filosofia, vêde a que riscos vos expusestes 
me conduzindo às alturas de vosso galardão! Estou aqui a falar-vos em demasia, expondo-vos com franqueza as minhas esperanças e os meus cuidados, e nem me apercebo de que vai adiantada a hora, que é tempo de dizer-vos como me sensibiliza e me confunde a vossa homenagem.

Estou naquela quadra da vida na qual ainda $\dot{e}$ cedo para parar, mas já começa a ser tarde para o balanço do já realizado. Generosamente quisestes dar o sinal de vosso aprêço pelo que me foi possível até agora fazer, mas recebo o vosso juizo sobretudo como uma prova de confiança no trabalho futuro, como desafio a que persevere na compreensão filosófica de uma experiência jurídica tão viva e fascinante como o é a dos juristas brasileiros, que nada têm a temer em confronto com a dos povos cultos. Se há um domínio do qual podemos nos envaidecer, ainda quando nos ignorem, êsse é o Direito, que a vossa Casa tão nobre e altamente representa! 